\title{
Safety Assessment of Osmolality Concentration and Biochemical Factors Changes in Electrolyte Metabolism during an Ultra-marathon (100 km)
}

\author{
Kyung-A Shin ${ }^{1}$ and Young-Joo Kim ${ }^{2}$ \\ ${ }^{1}$ Department of Clinical Laboratory Science, Shinsung University, Dangjin 31801, Korea \\ ${ }^{2}$ Department of Rehabilitation Medicine, Sanggye-Paik Hospital, Seoul 01757, Korea
}

\section{울트라 마라톤(100 km)에서 삼투압 농도와 전해질 대사의 생화학적 요인 변화에 대한 안전성 평가}

\author{
신경아 ${ }^{1}$, 김영주 $^{2}$ \\ ${ }^{1}$ 신성대학교 임상병리과, ${ }^{2}$ 상계백병원 재활의학과
}

\begin{abstract}
This study was conducted to investigate the electrolyte metabolic responses to a $100 \mathrm{~km}$ ultra-marathon in 22 male amateur runners. Their average age was $50.91 \pm 4.77$ years old and their $\mathrm{VO}_{2}$ max value was $48.19 \pm 6.43 \mathrm{~mL} / \mathrm{kg} / \mathrm{min}$. The participants completed the race with a mean finishing time of $205.55 \pm 19.61$ minute. Electrolyte parameters based on blood tests including calcium, inorganic phosphorus, magnesium, sodium, potassium, chloride, total carbon dioxide, anion gap, plasma volume change and osmolality were measured pre-race, at $50 \mathrm{~km}$, and at 100 $\mathrm{km}$ (post-race). Only slight changes in sodium level with no cases of hypernatremia or hyponatremia were observed. Additionally, all the electrolyte parameters changes were within the normal range and plasma volumes were unchanged. Overall, amateur marathon runners are not at risk to develop clinically significant electrolyte or osmolality changes during a $100 \mathrm{~km}$ ultra-marathon.
\end{abstract}

Keywords: Electrolyte, Endurance exercise, Osmolality, Plasma volume change

This is an Open Access article distributed under the terms of the Creative Commons Attribution Non-Commercial License (http://creativecommons.org/licenses/by-nc/4.0) which permits unrestricted non-commercial use, distribution, and reproduction in any medium, provided the original work is properly cited.

Copyright $(2016$ The Korean Society for Clinical Laboratory Science. All rights reserved.
Corresponding author: Young-Joo Kim Department of Rehabilitation Medicine, Sanggye-Paik Hospital, 1342 Dongil-ro, Nowon-gu, Seoul 01757, Korea Tel: 82-2-950-1383 Fax: 82-2-938-4109

E-mail: mobitz2@hanmail.net

Received: April 20, 2016 Revised $1^{\text {st: }}$ May 11, 2016 Revised $2^{\text {nd }}:$ May 24,2016 Revised 3 ${ }^{\text {rd: }}$ May 25, 2016 Revised 4 ${ }^{\text {th: }}$ : May 26, 2016 Accepted: May 26, 2016

\section{서 론}

장거리 지구력 운동은 인체에 다양한 생리적 변화를 일으키는 데, 에너지원의 고갈, 심박수 증가 및 혈관수축, 에너지 대사과정에 서 생긴 부산물의 축적으로 피로를 유발하며 이는 경기력 저하의 원인으로 작용한다[1]. 이러한 생리적 변화 중 다량의 땀 손실은 체 수분 및 전해질 손실을 초래하며, 체내의 전해질 불균형으로 근육
경련의 발생 가능성을 증가시킨다[2].

장거리 마라톤은 땀 손실이 많은 경기로 이로 인한 체수분 감소, 혈액농축, 혈장 삼투압 증가가 나타나면, 레닌, 안지오텐신, 알도스 테론과 항이뇨 호르몬에 의해 수분평형 조절이 이루어진다[3,4]. 그러나 장거리 마라톤 경기 중 부적절한 수분 공급에 따른 탈수 현 상은 혈장 삼투압, 혈장량, 전해질과 체액조절 호르몬에 영향을 미 쳐 경기력 저하뿐만 아니라 건강상의 문제를 야기한다[5]. 
특히 저나트륨혈증은 장거리 마라톤 경기에 있어서 가장 흔한 합병증 중 하나이며, 경기 중 주된 사망원인이 되고 있다[6]. 심각한 저나트륨혈증은 마라톤, 트라이애슬론(triathlon), 울트라 마라톤 에 참여하는 운동선수에게서 경기 중 빈번하게 발생한다[6-8]. 그 예로 Almond 등[8]은 2002년 보스톤 마라톤에서 488명의 주자들 중 혈중 소디움 농도가 $135 \mathrm{mEq} / \mathrm{L}$ 미만인 저나트륨혈증의 경우는 $13 \%, 120 \mathrm{mEq} / \mathrm{L}$ 미만인 치명적인 저나트륨혈증은 $0.6 \%$ 로 보고하 였다. 또 다른 연구는 울트라 마라톤 종료 후 $135 \mathrm{mEq} / \mathrm{L}$ 미만인 저 나트륨혈증이 $18 \%$ 였으며, 그 중 $130 \mathrm{mEq} / \mathrm{L}$ 미만인 저나트륨혈증 은 3.3\%로 나타났다[6]. Costa 등[9]은 수분공급에 따른 운동 중 체 액성분 변화에 대한 연구에서 울트라 지구력 달리기 중 수분공급은 충분하였으나 기준 권고치 이하의 나트륨을 섭취한 결과 경기 중 체수분 정상상태(euhydration)가 유지되었으며, 대부분의 선수들 이 정상 나트륨 수치를 보였다고 보고하였다.

이와 같은 전해질 대사의 위험요인으로는 장기간 운동, 여성, 운 동 중 과도한 체액소모, 비스테로이드성 항염증 약물 복용, 과도한 고온 및 저온환경 등이 제시되고 있다[10]. 장거리 지구력 운동선수 들의 체수분과 전해질 대사에 대한 연구는 장시간 운동에 의해 유 발될 수 있는 탈수 현상을 이해하는데 도움이 될 것이다. 그러나 선 행연구들은 엘리트 선수를 대상으로 경기 전후의 전해질 농도 차이 를 비교한 연구가 대부분이며, 경기 중 전해질 변화에 대해서는 언 급하지 못하였다 [6,8]. 또한 연구 대상자에 경기를 완주하지 못한 선수들도 일부 포함되어 있는 제한점을 가지고 있다[8]. 더욱이 운 동에 따른 혈액농축에 의한 혈장량 변화를 배제하였으며, 마라톤 이외에 울트라 마라톤 같은 장거리 지구성 운동을 즐기는 사람이 증가하고 있음에도 아마추어 선수에게서 장거리 지구력 운동이 전 해질 변화에 미치는 영향에 대한 연구는 미흡한 실정이다.

따라서 본 연구의 목적은 $100 \mathrm{~km}$ 울트라 마라톤 경기 전, $50 \mathrm{~km}$ 지점, 경기 종료 직후에 삼투압 농도 및 전해질 대사의 생화학적 변 화에 대해 알아보고 이를 통하여 $100 \mathrm{~km}$ 의 극심한 장거리 달리기 대회에서 수분공급의 적절성과 안전성을 검증하기 위함이다.

\section{대상 및 방법}

\section{1. 연구 대상}

본 연구의 대상자는 자발적으로 $100 \mathrm{~km}$ 울트라 마라톤에 참여 한 남자 지원자를 대상으로 하였다. $100 \mathrm{~km}$ 울트라 마라톤 참여자 들은 $100 \mathrm{~km}$ 울트라 마라톤 완주 경험이 2회 이상이고 $100 \mathrm{~km}$ 울 트라 마라톤을 15 시간 이내로 완주한 22 명을 대상자로 하였다. 대 상자들은 출발 2 시간 전에 안정 시 채혈을 하였으며, $50 \mathrm{~km}$ 지점, 경기 완주 직후 바로 채혈을 실시하였다. 대회 참여자들에게는 연
구의 목적과 절차에 대해 설명하였으며, 연구 참여에 동의한 대상 자 모두에게 동의서를 받았다. 대상자 중 완주에 실패한자, 경기 규 정시간 이내에 완주하지 못한자, 안정 시 혈압이 $\geq 140 / 90 \mathrm{mmHg}$ 인자, 운동유발성 고혈압자(안정 시 수축기혈압이 $<140 \mathrm{mmHg}$ 이면서 최대 운동시 수축기혈압이 $\geq 210 \mathrm{mmHg}$, 심혈관 질환, 당 뇨, 신장 질환, 간질환, 혈압약물을 복용 중 인자는 연구에서 제외하 였다. $100 \mathrm{~km}$ 울트라 마라톤대회의 평균시속은 $7.4 \mathrm{~km}$ 로 5월에 대회가 진행되었으며, 출발 시 기온은 $23^{\circ} \mathrm{C}$, 습도는 $50 \%$ 였다. 100 $\mathrm{km}$ 울트라 마라톤 코스 $25 \mathrm{~km}$ 간격으로 식수대를 준비하여 제공 하였으며, $50 \mathrm{~km}$ 지점에서 식사가 제공되었다. 모든 대상자들의 개인 병력에 대한 정보는 설문지를 통하여 얻었다. 본 연구는 인제 대학교 상계백병원 연구윤리심의위원회(IRB)의 심의를 거쳐 진행 하였다(No. 2013-10-95).

\section{2. 연구방법}

\section{1) 신체계측}

신장 계측기는 STDK-AD (Shintokyo Desshikizai Co., Tokyo, Japan)로, 체중 계측기는 YK-150N (Yagami Inc., Tokyo, Japan) 으로 측정하였다. 체질량지수(body mass index, BMI)는 몸무게 $(\mathrm{kg}) / \exists \mid\left(\mathrm{m}^{2}\right)$ 공식으로 구했다.

\section{2) 운동부하검사}

연구대상자에게 운동부하검사를 실시한 목적은 선수들의 안정 성 검사와 운동 중 잠재된 질환(고혈압, 부정맥, 심근 허혈)을 조사 하여 연구대상에서 제외될 조건을 찾고 추가적으로 선수들의 기본 혈역학 반응과 심폐체력 수준을 파악하기 위함이다.

운동부하검사는 3 분마다 경사도와 빠르기가 증가하는 Bruce protocol을 이용하여 미국심장학회(America College of Cardiology, $\mathrm{ACC}$ ) 및 미국심장협회(American Heart Association, $\mathrm{AHA}$ )의 지 침에 따라 검사하였다. 검사는 12 채널 실시간 운동부하 검사용 심 전도 검사기 Q4500 (Quinton Instrument Co., Boston, USA) 및 호흡가스 분석기 QMC (Quinton Instrument Co., Boston, USA) 를 이용하여 최대산소섭취량(maximum oxygen consumption, $\mathrm{VO}_{2} \max$ )을, 자동혈압 및 맥박 측정기 Model 412 (Quinton Instrument Co., Boston, USA)를 이용하여 혈압을 측정하였으며, 운동부하 검사용 트레드밀 기기 Medtrack ST 55 (Quinton Instrument Co., Boston, USA)를 사용하였다. 검사 중 환자의 흥 통, 어지러움 같은 자각증상이나 모니터 상 위험한 심장사건과 이 상 혈압반응이 나타날 경우 미국심장학회 및 미국심장협회의 지침 에 근거하여 검사를 종료하였다. 운동부하검사 전 안정 시 심박수 와 혈압을 측정하였으며, 연구 대상자는 안정 시와 운동부하검사 
중 각 단계별로 단계를 마치기 1 분전에 심박수, 혈압, 최대산소섭 취량을 기록하였다.

\section{3) 혈액검사}

삼투압 농도(osmolality)는 빙점 강하법(freezing point depression) 원리로 The Advanced Micro Osmometer Model 3300 (Advanced Instruments Inc., Maryland, USA)을 이용하여 측정하였다. 혈장 전해질인 소디움(sodium, $\mathrm{Na}^{+}$), 포타슘(potassium, $\mathrm{K}^{+}$), 염소(chloride, $\mathrm{Cl}^{-}$)는 간접 이온전극선택법(ionselective electrode, ISE), 칼슘(calcium, $\mathrm{Ca}$ )은 o-CPC (o-cresol phthalein complexone), 무기인(inorganic phosphate, IP)은 photometric $\mathrm{UV}$ 법, 총이산화탄소(total $\mathrm{CO}_{2}, \mathrm{TCO}_{2}$ )는 enzymatic UV법, 마그 네슘은 formazan법의 원리로 TBA-200FR NEO (Toshiba, Tokyo, Japan)를 이용하여 측정하였다. 음이온 차이(anion gap) 는 $\left(\mathrm{Na}^{+}+\mathrm{K}^{+}\right)-\left(\mathrm{Cl}^{-}+\left[\mathrm{HCO}_{3}{ }^{-}\right]\right)$공식에 의해 계산하였으며, 헤모글로 빈(hemoglobin, $\mathrm{Hb}$ )과 헤마토크리트(hematocrit, Hct) 측정은 자 동혈액분석기 Beckman Coulter LH 750 (Beckman Coulter, Miami, FL, USA) 장비를 이용하여 측정하였다. 또한 혈액농축에 의한 혈장량 변화(plasma volume change, PVC)는 아래의 공식에 의해 산출하였다[11]. 전해질에 대한 혈장량 변화는 Dill과 Costill[12]이 제시한 방법에 의해 보정하여 결과를 제시하였다.

$$
\mathrm{PVC}=\frac{100 \text { (경기전헤마토크리트-경기후헤마토크리트 })}{\text { 경기후헤마토크리트 }}
$$

\section{3. 통계분석}

본 연구의 자료 분석은 Windows SPSS 21.0 (IBM, Armonk, USA) 통계프로그램을 사용하였으며, 모든 자료는 평균과 표준편

Table 1. Subject characteristics $(\mathrm{N}=22)$

\begin{tabular}{lc}
\hline \multicolumn{1}{c}{ Variable } & Mean \pm SD \\
\hline Age (year) & $50.91 \pm 4.77$ \\
Height $(\mathrm{cm})$ & $168.74 \pm 4.30$ \\
Weight $(\mathrm{kg})$ & $66.55 \pm 6.39$ \\
Body mass index $\left(\mathrm{kg} / \mathrm{m}^{2}\right)$ & $23.35 \pm 1.79$ \\
Resting heart rate $(\mathrm{bpm})$ & $64.32 \pm 9.26$ \\
Maximal heart rate $(\mathrm{bpm})$ & $167.18 \pm 11.23$ \\
Resting SBP $(\mathrm{mmHg})$ & $121.00 \pm 10.04$ \\
Resting DBP $(\mathrm{mmHg})$ & $72.95 \pm 8.57$ \\
Maximal SBP $(\mathrm{mmHg})$ & $247.73 \pm 16.89$ \\
Maximal DBP $(\mathrm{mmHg})$ & $68.55 \pm 13.69$ \\
VO $O_{2}$ max $(\mathrm{mL} / \mathrm{kg} / \mathrm{min})$ & $48.19 \pm 6.43$ \\
Race time $(\mathrm{min})$ & $829.64 \pm 89.31$ \\
\hline
\end{tabular}

Abbreviation: SBP, systolic blood pressure; DBP, diastolic blood pressure.
차로 나타냈다. $100 \mathrm{~km}$ 울트라 마라톤 경기 전, $50 \mathrm{~km}$, 경기 종료 직후에 헤모글로빈, 헤마토크리트, 혈장량과 삼투압 농도 및 전해 질 변화를 검증하기 위해 반복측정 분산분석(one-way repeated measured ANOVA)으로 분석하였으며, 시기간 사후검증은 bonferroni를 적용하였다. 결과에 대한 통계적 유의수준은 $p<0.05$ 로 설정하였다.

\section{결 과}

\section{1. 연구대상자의 개인적 특징}

$100 \mathrm{~km}$ 울트라 마라톤 주자 22명의 평균 연령은 $50.91 \pm 4.77$ 세이며, 체질량지수는 $23.35 \pm 1.79$ 였다. 안정 시 심박수는 $64.32 \pm 9.26 \mathrm{bpm}$, 운동 시 최대심박수는 $167.18 \pm 11.23 \mathrm{bpm}$ 이 었다. 안정 시 수축기혈압은 $121.00 \pm 10.04 \mathrm{mmHg}$ 이었으며, 안 정 시 이완기혈압은 $72.95 \pm 8.57 \mathrm{mmHg}$ 이었다. 최대 운동 시 수축 기혈압은 $247.73 \pm 16.89 \mathrm{mmHg}$ 이었으며, 최대 운동 시 이완기혈 압은 $68.55 \pm 13.69 \mathrm{mmHg}$ 이었다. 최대산소소비량은 $48.19 \pm 6.43$ $\mathrm{mL} / \mathrm{kg} / \mathrm{min}$ 이었으며, $100 \mathrm{~km}$ 울트라 마라톤 평균 경기시간은 829.64 \pm 89.31 분이었다(Table 1).

\section{2. $100 \mathrm{~km}$ 울트라 마라톤 각 구간별 헤모글로빈, 헤마토크리트, 혈장량 변화}

$100 \mathrm{~km}$ 울트라 마라톤 각 구간별 헤모글로빈 농도는 경기 전 $(14.33 \pm 0.84 \mathrm{~g} / \mathrm{dL})$ 보다 $50 \mathrm{~km}(14.74 \pm 0.97 \mathrm{~g} / \mathrm{dL})$ 와 $100 \mathrm{~km}$ $(14.63 \pm 0.99 \mathrm{~g} / \mathrm{dL})$ 에서 각각 유의한 증가를 보였으나 $(p=0.002)$, 헤마토크리트는 경기 전(42.25 $2.30 \%)$ 과 비교하여 $50 \mathrm{~km}$ $(42.81 \pm 2.45 \%)$ 와 $100 \mathrm{~km}(42.38 \pm 2.66 \%)$ 에서 차이가 없었다. 또한 혈장량도 $50 \mathrm{~km}(-3.75 \pm 4.37 \%)$ 와 $100 \mathrm{~km}(-2.05 \pm 6.20 \%)$ 에서 유의한 변화가 없는 것으로 나타났다(Table 2).

\section{3. $100 \mathrm{~km}$ 울트라 마라톤 각 구간별 삼투압 농도 및 전해질 변화}

$100 \mathrm{~km}$ 울트라 마라톤 각 구간별 삼투압 농도는 경기 전

Table 2. Changes in $\mathrm{Hb}$, Hct, plasma volume during the $100 \mathrm{~km}$ ultra-marathon

\begin{tabular}{lcccc}
\hline \multicolumn{1}{c}{ Variable } & Pre-race & $50 \mathrm{~km}$ & $100 \mathrm{~km}$ & $p$ \\
\hline $\begin{array}{l}\text { Hemoglobin } \\
\text { (g/dL) }\end{array}$ & $14.33 \pm 0.84$ & $14.74 \pm 0.97^{\star}$ & $14.63 \pm 0.99^{\star}$ & 0.002 \\
Hematocrit (\%) & $42.25 \pm 2.30$ & $42.81 \pm 2.45$ & $42.38 \pm 2.66$ & 0.141 \\
$\begin{array}{l}\text { Plasma volume } \\
\text { change (\%) }\end{array}$ & $-3.75 \pm 4.37$ & $-2.05 \pm 6.20$ & 0.101 \\
\hline
\end{tabular}

Calculated by repeated measured ANOVA and bonferroni test. *Significantly different from pre-race at $p<0.05$. 
(300.90 $\left.\pm 5.00 \mathrm{mOsm} / \mathrm{kgH}_{2} \mathrm{O}\right), 50 \mathrm{~km}(303.51 \pm 9.21 \mathrm{mOsm} /$ $\left.\mathrm{kgH}_{2} \mathrm{O}\right), 100 \mathrm{~km}\left(304.07 \pm 8.65 \mathrm{mOsm} / \mathrm{kgH}_{2} \mathrm{O}\right)$ 로 차이가 없었 다. 칼슘은 경기 전 $(9.49 \pm 0.31 \mathrm{mg} / \mathrm{dL})$ 보다 $50 \mathrm{~km}(9.77 \pm 0.43$ $\mathrm{mg} / \mathrm{dL})$ 와 $100 \mathrm{~km}(9.66 \pm 0.42 \mathrm{mg} / \mathrm{dL})$ 에서 각각 유의하게 증가 하였다 $(p<0.001)$. 무기인은 경기 전 $(3.80 \pm 0.48 \mathrm{mg} / \mathrm{dL})$ 보다 50 $\mathrm{km}(5.08 \pm 0.88 \mathrm{mg} / \mathrm{dL})$ 에서 유의하게 증가하였으며, $100 \mathrm{~km}$ $(5.60 \pm 0.90 \mathrm{mg} / \mathrm{dL})$ 는 경기 전과 $50 \mathrm{~km}$ 보다 유의하게 증가하였 다 $(p<0.001)$. 마그네슘은 경기 전 $(2.20 \pm 0.13 \mathrm{mg} / \mathrm{dL})$ 보다 50 $\mathrm{km}(2.12 \pm 0.11 \mathrm{mg} / \mathrm{dL})$ 에서 유의하게 감소하였다 $(p=0.041)$. 염 소는 경기 전 $(100.90 \pm 1.82 \mathrm{mEq} / \mathrm{L})$ 보다 $50 \mathrm{~km}(100.48 \pm 2.36$ $\mathrm{mEq} / \mathrm{L})$ 와 $100 \mathrm{~km}(99.08 \pm 3.56 \mathrm{mEq} / \mathrm{L})$ 에서 각각 유의하게 감소 하였다 $(p=0.029)$. 총이산화탄소는 경기 전 $(26.28 \pm 1.61 \mathrm{mEq} / \mathrm{L})$ 보다 $50 \mathrm{~km}(23.93 \pm 1.93 \mathrm{mEq} / \mathrm{L})$ 에서 유의하게 감소하였으며, $100 \mathrm{~km}(22.50 \pm 2.20 \mathrm{mEq} / \mathrm{L})$ 는 경기 전과 $50 \mathrm{~km}$ 보다 유의하게 감소하였다 $(p<0.001)$. 음이온 차이는 경기 전(16.68 \pm 1.85$)$ 보다 $50 \mathrm{~km}(19.55 \pm 2.04)$ 와 $100 \mathrm{~km}(20.60 \pm 4.21)$ 에서 각각 유의하 게 증가하였다 $(p<0.001$ ) (Table 3). 소디움은 경기 전(139.77 \pm 1.50 $\mathrm{mEq} / \mathrm{L})$ 과 $50 \mathrm{~km}(139.55 \pm 2.23 \mathrm{mEq} / \mathrm{L})$ 보다 $100 \mathrm{~km}(137.85 \pm 3.11$ $\mathrm{mEq} / \mathrm{L}$ )에서 유의한 감소를 보였으며( $p=0.004)$ (Fig. 1), 포타슘은

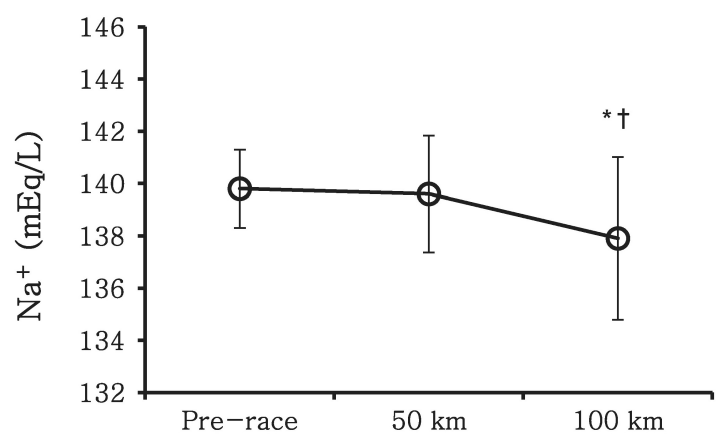

Fig. 1. Changes in sodium concentration during the $100 \mathrm{~km}$ ultra-marathon. *Significantly different from pre-race at $p<0.05$. ${ }^{+}$Significantly different from $50 \mathrm{~km}$ at $p<0.05$.
경기 전 $(4.09 \pm 0.19 \mathrm{mEq} / \mathrm{L})$ 보다 $50 \mathrm{~km}(4.42 \pm 0.35 \mathrm{mEq} / \mathrm{L})$ 와 $100 \mathrm{~km}(4.33 \pm 0.39 \mathrm{mEg} / \mathrm{L})$ 에서 각각 유의한 증가를 보였다 ( $p=0.002)$ (Fig. 2).

\section{고 찰}

본 연구에서는 $100 \mathrm{~km}$ 울트라 마라톤 출발 전, $50 \mathrm{~km}$ 지점, 경 기 종료 직후에 삼투압 농도 및 전해질 대사의 생화학적 변화를 통 해 장거리 지구력 운동에서 수분공급의 적절성과 안전성을 검증하 고자 하였다.

울트라 장거리 달리기와 같은 장시간 지속적인 운동은 선수 건 강을 위협하고, 인체에 일시적으로 부정적인 반응을 일으키는 것으 로 알려져 있다. 장시간 운동에 의해 체액은 혈장에서 근섬유로 이 동하여 혈장 삼투압이 증가하고, 혈장량 감소에 따른 혈액농축 현 상이 야기된다[3,4]. 또한 이에 따른 근섬유로의 혈액공급이 감소 하여 운동능력이 떨어지는 결과가 나타난다[2]. 이와 같이 혈장 삼 투압 증가, 혈액농축 및 혈장 소디움, 포타슘의 상대적 비율 증가는 체액이 수분 불균형 상태임을 설명해주는 지표이다[2-5].

Knechtle 등[13]은 $100 \mathrm{~km}$ 울트라 마라톤 후 헤모글로빈과 헤 마토크리트가 감소하여 산소 운반능력에 변화를 보였으며, 혈장량

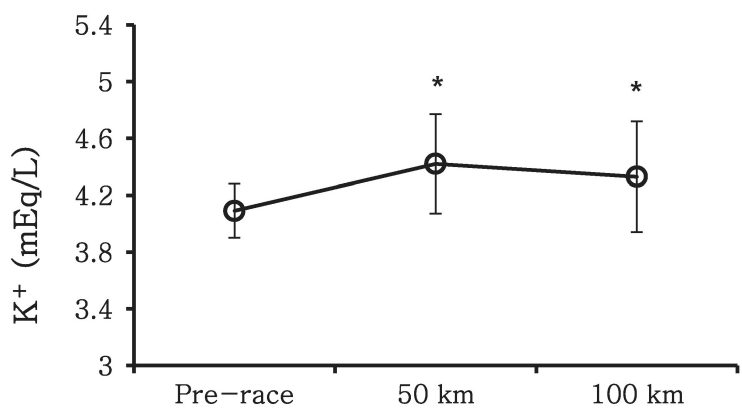

Fig. 2. Changes in potassium concentration during the $100 \mathrm{~km}$ ultra-marathon. ${ }^{*}$ Significantly different from pre-race at $p<0.05$.

Table 3. Changes in osmolality, electrolyte during the $100 \mathrm{~km}$ ultra-marathon

\begin{tabular}{lrrrr}
\hline \multicolumn{1}{c}{ Variable } & \multicolumn{1}{c}{ Pre-race } & $50 \mathrm{~km}$ & $100 \mathrm{~km}$ & $p$ \\
\hline Osmolality $\left(\mathrm{mOsm} / \mathrm{kgH}_{2} \mathrm{O}\right)$ & $300.90 \pm 5.00$ & $303.51 \pm 9.21$ & $304.07 \pm 8.65$ & 0.299 \\
Calcium $(\mathrm{mg} / \mathrm{dL})$ & $9.49 \pm 0.31$ & $9.77 \pm 0.43^{*}$ & $9.66 \pm 0.42^{\star}$ & $<0.001$ \\
Inorganic phosphorus $(\mathrm{mg} / \mathrm{dL})$ & $3.80 \pm 0.48$ & $5.08 \pm 0.88^{*}$ & $5.60 \pm 0.90^{*}$ & $<0.001$ \\
Magnesium $(\mathrm{mg} / \mathrm{dL})$ & $2.20 \pm 0.13$ & $2.12 \pm 0.11^{*}$ & $2.20 \pm 0.17$ & 0.041 \\
Chloride $(\mathrm{mEq} / \mathrm{L})$ & $100.90 \pm 1.82$ & $100.48 \pm 2.36^{*}$ & $99.08 \pm 3.56^{*}$ & 0.029 \\
Total $\mathrm{CO}_{2}(\mathrm{mEq} / \mathrm{L})$ & $26.28 \pm 1.61$ & $23.93 \pm 1.93^{*}$ & $22.50 \pm 2.20^{*}$ & $<0.001$ \\
Anion gap & $16.68 \pm 1.85$ & $19.55 \pm 2.04^{*}$ & $20.60 \pm 4.21^{*}$ & $<0.001$ \\
\hline
\end{tabular}

Calculated by repeated measured ANOVA and bonferroni test.

* Significantly different from pre-race at $p<0.05$.

${ }^{\dagger}$ Significantly different from $50 \mathrm{~km}$ at $p<0.05$. 
의 증가를 보고하였다. 본 연구결과 $100 \mathrm{~km}$ 울트라 마라톤 경기에 서 헤모글로빈은 증가하였으나, 혈장량과 삼투압 농도는 각 구간별 변화가 없었다. 또한 소디움은 경기 전과 $50 \mathrm{~km}$ 지점보다 $100 \mathrm{~km}$ 지점에서 약 $2 \mathrm{mEq} / \mathrm{L}$ 감소하였으며, 소디움 농도가 130 135 $\mathrm{mEq} / \mathrm{L}$ 인 저나트륨혈증의 경우는 4건(18\%) 나타났다. 그러나 저 나트륨혈증은 운동에 따른 혈장량, 즉 혈액농축 현상을 보정한 결 과 발생하지 않았다.

중년 마라톤 주자들에게서 경기 후 혈청 소디움 농도는 변화가 없거나 증가 또는 감소한다는 다양한 결과가 보고되고 있다 [7,14,15]. 장시간 운동에서 소디움의 근세포막 투과도 증가로 근 육에서 세포외액으로 소디움 배출 증가 때문에 고나트륨혈증을 유 발할 수 있다고 보고된다[4]. 그러나 본 연구결과 $100 \mathrm{~km}$ 지점에서 의 소디움 농도 감소는 주로 미세한 혈장량의 변화에 의한 것이며, 참고범위 내에서의 변화로 적절한 체수분 상태(euhydration)를 유 지하고 있음을 추측할 수 있었다. 이러한 운동에 따른 소디움 농도 이상은 불충분한 수분섭취나 수분 과잉상태와 같이 수분공급이 적 절하게 이루어지지 않은 경우에 주로 나타나는데, 본 연구결과에서 는 극심한 장거리 달리기인 $100 \mathrm{~km}$ 울트라 마라톤 경기 시 주최측 에서 제공하는 수분이 적절하게 공급된 것을 유추할 수 있었다[16]. 그러나 전해질 농도만으로 체내의 수분과 염분조절을 정확히 평가 하기에는 한계가 있으며, 알도스테론과 바소프레신 등의 호르몬 연 구가 필요하겠다.

소디움, 포타슘은 심장 및 신경근육세포의 안정막 전위와 활동 전위를 발생하는데 중요한 역할을 담당하며, 체액 평형 조절을 담 당하는 대표적인 전해질이다[5]. 혈장 소디움, 포타슘 농도는 체액 조절 호르몬인 알도스테론에 의해 조절되며, 포타슘 농도의 증가는 골격근과 심근에 과도한 흥분을 생성하여 심한 경우 심실세동 (ventricular fibrillation)과 같은 심각한 부정맥을 유발하게 된다 [17].

본 연구결과 포타슘 농도는 경기 전보다 $50 \mathrm{~km}$ 와 $100 \mathrm{~km}$ 지점 에서 유의한 증가를 보였으며, 선행연구의 결과에서도 경기 중 혈 중 포타슘 농도가 점진적으로 상승하여 본 연구와 유사한 결과를 보이고 있다[14]. $100 \mathrm{~km}$ 지점에서의 포타슘 농도 증가는 운동 중 골격근으로부터 혈중으로 포타슘이 유출되기 때문이다[2]. 또한 포타슘의 증가는 신경의 안정막 전위를 변동시켜 골격근의 흥분 자 극이 과도하게 증가될 수 있으며, 선수들에게 있어서 포타슘 농도 의 증가는 근육통 및 근경련을 일으키는 요인으로 추측되고 있다 [2,5]. 그러나 본 연구결과 포타슘 농도의 상승은 참고범위 내에서 의 변화로 $100 \mathrm{~km}$ 울트라 마라톤에서 포타슘 농도는 항상성을 유 지하고 있음을 알 수 있었다.

혈중 칼슘과 무기인은 체내의 에너지 대사에 관여하고, 뼈의 주
요 구성성분이다. Bourrin 등[18]은 운동부하 결과 혈중 칼슘과 무 기인 농도가 감소하였음을 보고하였으며, Kratz 등[15]은 마라톤 경기 종료 후 무기인이 증가하는 상반된 결과를 보고하였다. 무기 인은 ATP가 가수분해되어 방출되는데[17], 본 연구결과 무기인과 칼슘은 경기 전보다 $100 \mathrm{~km}$ 지점에서 증가하였다. 이와 같은 무기 인의 상승은 $100 \mathrm{~km}$ 장거리 마라톤 경기 시 근육의 에너지 대사과 정에서 ATP가 가수분해되면서 혈중으로 유리되어, 무기인 농도가 증가한 것으로 사료된다[19]. 본 연구 저자들은 마라톤 주자를 대상 으로 한 이전 연구에서 나트륨과 염소는 경기 완주 직후 안정 시보 다 상승하며, 포타슘과 칼슘은 변화가 없다는 결과를 보고하였다 [20]. 마라톤 경기는 평균 시속 $11.3 \mathrm{~km}$ 의 고강도 운동이며, 100 $\mathrm{km}$ 울트라 마라톤은 평균 시속 $7.4 \mathrm{~km}$ 의 중고강도 운동에 해당하 므로 운동강도에 따라 상반된 결과를 나타내는 것을 알 수 있었다.

마그네슘은 정상적인 신경 및 근육 기능, 심장박동(심장 흥분 성), 혈관 운동긴장(vasomotor tone), 혈압, 면역계, 골의 완전성 (bone integrity) 및 혈당을 유지하는 데 중요한 역할을 하며, 칼슘 흡수를 촉진시킨다[21]. 선행연구는 고온 환경에서 장시간 격렬한 운동이 저마그네슘혈증을 초래할 수 있다고 보고하였다[22]. 본 연 구결과 마그네슘은 경기 전보다 $50 \mathrm{~km}$ 지점에서 참고범위 내에서 유의한 감소를 보였다. 이와 같은 마그네슘 저하의 기전은 운동에 따른 적혈구, 지방세포 및 근세포로의 마그네슘 재분배 때문으로 생각된다[23]. 또 다른 주요한 기전으로 알도스테론, 항이뇨 호르 몬, 갑상선 호르몬의 증가로 인한 소변으로의 유실과 세뇨관에서의 마그네슘 재흡수의 감소 또는 운동에 의해 유발된 카테콜라민의 상 승으로 인한 지방분해의 증가가 제시된다[24].

한편, 중년뿐 아니라 청년을 대상으로 한 연구에서도 운동에 의 해 다양한 환기반응이 나타나는데, 반응의 특징은 저이산화탄소증 (hypocapnia) 및 호흡성 알칼리증과 연관된 빈호흡(tachypnea) 이다[16,25]. 특히 저이산화탄소증은 대사활성조직에서 생산하는 이산화탄소보다 폐에서 더 많은 이산화탄소를 제거하는 강한 호흡 자극이 야기될 때 발현된다[16]. 본 연구결과 총이산화탄소 농도는 경기 전보다 $50 \mathrm{~km}$ 지점에서 감소하였으며, $50 \mathrm{~km}$ 지점보다는 $100 \mathrm{~km}$ 지점에서 감소하였다. 이와 같은 운동 중 혈장 총이산화탄 소와수소 $\left[\mathrm{H}^{+}\right]$농도의 감소에 의해 유발된 과호흡은 혈관협착과 혈 류량 감소로 운동근으로의 산소 운반을 제한할 수 있다[25]. 그러나 본 연구결과에서의 총이산화탄소의 변화는 참고범위 내에서의 변 화로 $100 \mathrm{~km}$ 울트라 마라톤 경기 중이나 경기 종료 직후에도 항상 성을 유지하고 있는 것으로 나타났다. 또한 음이온 차이는 경기 전 보다 $50 \mathrm{~km}, 100 \mathrm{~km}$ 지점에서 증가하였는데, 이는 양이온인 포타 슘의 증가와음이온인 염소, 총이산화탄소의 감소 때문으로 나타났다.

본 연구의 제한점으로는 주자들이 $25 \mathrm{~km}$ 지점마다 수준섭취의 
용량과 개인적인 수분조달을 통제하지 못했다. 또한 수분섭취와 관 련된 호르몬을 조사하기 못했으며, 선수들의 체중변화와 $100 \mathrm{~km}$ 울트라 마라톤 후 회복기 반응에 대해서 평가가 이루어지지 못했 다. 본 연구를 통해 $100 \mathrm{~km}$ 울트라 마라톤에서 혈장량과 삼투압 변 화는 없었으며, 소디움은 경기 전과 $50 \mathrm{~km}$ 지점보다 $100 \mathrm{~km}$ 지점 에서 감소하였으나 저나트륨혈증을 유발하지는 않았다. 이를 통해 $100 \mathrm{~km}$ 울트라 마라톤 중 적절한 수분 공급이 이루어졌음을 알 수 있었다. 또한 포타슘, 칼슘, 마그네슘, 총이산화탄소의 변화는 항상 성을 유지하는 참고범위 내에서 이루어진 것을 알 수 있었으며, $100 \mathrm{~km}$ 울트라 마라톤이 전해질 대사에 있어서는 선행연구에서 나타나는 부작용이나 위험성을 발견할 수 없어 안전한 것으로 나타 났다. 그러나 몇몇 $100 \mathrm{~km}$ 울트라 마라톤 경기에서는 주최측에서 의 식수공급이 없거나 $25 \mathrm{~km}$ 이상의 구간에서 수분이 공급되는 대 회들이 있다. 이러한 대회들은 수분 불균형의 위험성이 내제되어 있으므로, 본 연구결과를 토대로 타 경기에서도 전해질 대사의 안 전성에 대한 추가 연구가 필요할 것으로 생각된다.

\section{요 약}

본 연구는 22 명의 남자 아마추어 선수를 대상으로 $100 \mathrm{~km}$ 울트 라마라톤에서의 전해질 대사 반응의 안전성을 평가하기 위해 실시

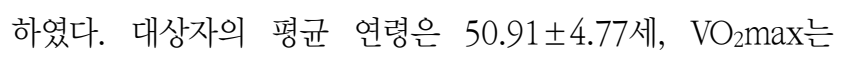
$48.19 \pm 6.43 \mathrm{~mL} / \mathrm{kg} / \mathrm{min}$, 그리고 평균 경기 완주시간은 $829.64 \pm 89.31$ 분이었다. 혈액검사에 포함된 전해질 지표로는 칼 슘, 무기인, 마그네슘, 소디움, 포타슘, 염소, 총이산화탄소, 음이온 차이, 혈장량 변화와삼투압 농도를 경기 전, $50 \mathrm{~km}$ 지점, 경기 종료 직후 측정하였다. 본 연구결과 소디움 농도는 경기 전보다 $50 \mathrm{~km}$ 지점에서 감소하였고 $50 \mathrm{~km}$ 지점보다 $100 \mathrm{~km}$ 지점에서 감소하였 으나, 고나트륨혈증 및 저나트륨혈증은 나타나지 않았다. $100 \mathrm{~km}$ 울트라 마라톤 경기에서 다른 모든 전해질 지표들의 거리별 변화는 참고범위 내에서 이루어졌으며, 혈장량 변화는 나타나지 않았다. 결론적으로 아마추어 지구력 선수들의 전해질 대사에 있어서 경기 중 통계적인 차이는 있었으나 임상적으로 의미 있는 삼투압 농도와 전해질의 변화는 나타나지 않았으며 안전한 경기로 나타났다.

\section{Acknowledgements: None \\ Funding: None \\ Conflict of interest: None}

\section{References}

1. Kim KJ. Physiological characteristics, diet, and hydration of marathon runners. Journal of Coaching Development. 2005; 7:95-105.

2. Maughan RJ, Meyer NL. Hydration during intense exercise training. Nestle Nutr Inst Workshop Ser. 2013;76:25-37.

3. Melin B, Jimenez C, Savourey G, Bittel J, Cottet-Emard JM, Pequignot JM, et al. Effects of hydration state on hormonal and renal responses during moderate exercise in the heat. Eur J Appl Physiol Occup Physiol. 1997;76:320-327.

4. Takamata A, Ito T, Yaegashi K, Takamiya H, Maegawa Y, Itoh T, et al. Effect of an exercise-heat acclimation program on body fluid regulatory responses to dehydration in older men. Am J Physiol. 1999;277:R1041-1050.

5. Lim IS. The changes of electrolyte and fluid-regulating hormones concentration in the collapsed runners during marathon race. Korean J Physical Education. 2006;45:489-499.

6. Speedy DB, Noakes TD, Rogers IR, Thompson JM, Campbell RG, Kuttner JA, et al. Hyponatremia in ultradistance triathletes. Med Sci Sports Exerc. 1999;31:809-815.

7. Kłapcińska B, Waśkiewicz Z, Chrapusta SJ, Sadowska-Krępa E, Czuba M, Langfort J. Metabolic responses to a 48-h ultra-marathon run in middle-aged male amateur runners. Eur J Appl Physiol. 2013;113:2781-2793.

8. Almond CS, Shin AY, Fortescue EB, Mannix RC, Wypij D, Binstadt BA, et al. Hyponatremia among runners in the Boston Marathon. N Engl J Med. 2005;352:1550-1556.

9. Costa RJ, Teixeira A, Rama L, Swancott AJ, Hardy LD, Lee B, et al. Water and sodium intake habits and status of ultra-endurance runners during a multi-stage ultra-marathon conducted in a hot ambient environment: and observational field based study. Nutr J. 2013;12:13.

10. Hew-Butler T, Ayus JC, Kipps C, Maughan RJ, Mettler S, Meeuwisse WH, et al. Statement of the second international exercise-associated hyponatremia consensus development conference, New Zealand, 2007. Clin J Sport Med. 2008;8:111-121.

11. van Beaumont W, Strand JC, Petrofsky JS, Hipskind SG, Greenleaf JE. Changes in total plasma content of electrolytes and proteins with maximal exercise. J Appl Physiol. 1973; 34:102-106.

12. Dill DB, Costill DL. Calculation of percentage changes in volumes of blood, plasma, and red cells in dehydration. J Appl Physiol. 1974;37:247-248.

13. Knechtle B, Knechtle P, Rosemann T. Low prevalence of exercise-associated hyponatremia in male $100 \mathrm{~km}$ ultra-marathon runners in Switzerland. Eur J Appl Physiol. 2011;111: 1007-1016.

14. Nelson PB, Ellis D, Fu F, Bloom MD, O'Malley J. Fluid and electrolyte balance during a cool weather marathon. Am J Sports Med. 1989;17:770-772.

15. Kratz, A., Lewandrowski, KB, Siegel, AJ, Chun, KY, Flood, JG, Van Cott, EM et al. Effect of marathon running on hematologic and biochemical laboratory parameters, including cardiac markers. Am J Clin Pathol. 2002;118:856-863.

16. Waśkiewicz Z, Kł apcińska B, Sadowska-Krępa E, Czuba M, Kempa K, Kimsa E, et al. Acute metabolic responses to a 24-h 
ultra-marathon race in male amateur runners. Eur J Appl Physiol. 2012;112:1679-1688.

17. Lim IS. Hypokalemia and hyperkalemia. Korean J Pediatr. 2006; 49:470-474.

18. Bourrin S, Ghaemmaghami F, Vico L, Chappard D, Gharib C, Alexandre C. Effect of a five-week swimming program on rat bone: a histomorphometric study. Calcif Tissue Int. 1992; $51: 137-142$.

19. Roh HT, Ryu JH, Cho SY. Change in serum parameters of organ function, physiological variables and cytokines according to the distance covered among amateur marathoners. Korean J Physical Education. 2011;50:321-330.

20. Kim YJ, Lee YH, Shin KA. Effects of amateur marathon races on general hematologic factors. Korean J Sport. 2012;10:531-541.

21. Volpe SL. Magnesium and the athlete. Curr Sports Med Rep.
2015;14: 279-283.

22. Franz KB, Rüddel H, Todd GL, Dorheim TA, Buell JC, Eliot RS Physiologic changes during a marathon, with special reference to magnesium. J Am Coll Nutr. 1985;4:187-194.

23. Haymes EM. Vitamin and mineral supplementation to athletes. Int J Sport Nutr. 1991;1:146-169.

24. Rayssiguier Y. Hypomagnesemia resulting from adrenaline infusion in ewes: its relation to lipolysis. Horm Metab Res. 1977;9:309-314.

25. Chin LM, Leigh RJ, Heigenhauser GJ, Rossiter HB, Paterson DH, Kowalchuk JM. Hyperventilation-induced hypocapnic alkalosis slows the adaptation of pulmonary $\mathrm{O}_{2}$ uptake during the transition to moderate-intensity exercise. J Physiol. 2007;583: 351-364. 